\title{
SISTEM PANAS BUMI DAN MODEL KONSEPTUAL DAERAH PANAS BUMI GUNUNG UNGARAN, JAWA TENGAH
}

\author{
GEOTHERMAL SYSTEM \& CONCEPTUAL MODEL OF \\ GUNUNG UNGARAN GEOTHERMAL AREA, CENTRAL JAVA
}

\author{
Oleh: \\ Yuanno Rezky, Ahmad Zarkasyi, Dikdik Risdianto \\ Pusat Sumber Daya Geologi \\ Jl. Soekarno Hatta No. 444 Bandung
}

\section{SARI}

Penyelidikan dan penelitian geosain di daerah panas bumi Gunung Ungaran telah banyak dilakukan namun belum menghasilkan suatu model konseptual terpadu. Hasil kompilasi data penelitian terdahulu menunjukkan tiga kelompok daerah panas bumi di sekitar Ungaran yaitu Gedongsongo, Nglimut dan Kendalisodo dengan manifestasi berupa mata air panas, fumarol, tanah panas, dan batuan ubahan. Model konseptual panas bumi Gunung Ungaran menggambarkan geometri sistem panas bumi yang mencakup batuan penudung, reservoir, batuan dasar, sumber panas, serta isotermal dari kompilasi seluruh data yang ada.

Kata kunci: panas bumi, Gunung Ungaran, model konseptual

\section{ABSTRACT}

Geoscientific investigation and research in Gunung Ungaran geothermal area had been carried out in numbers but integrated conceptual model of geothermal system is not defined yet. The result of compiled data from previous research shows that there are three groups of geothermal features around Ungaran, namely Gedongsongo, Nglimut and Kendalisodo. The surface manifestations are include hot springs, fumaroles, hot grounds, and altered rocks. Conceptual model of Ungaran geothermal field describes the geometry of geothermal system including cap rocks, reservoir, basement rocks, heat source, and isothermal data.

Key words: geothermal, Gunung Ungaran, conceptual model

\section{PENDAHULUAN}

Wilayah kerja pertambangan (WKP) panas bumi Gunung Ungaran, Kabupaten Semarang dan Kabupaten Kendal, Jawa Tengah, ditetapkan berdasarkan Keputusan Menteri Energi dan Sumber Daya Mineral No. $1789 \mathrm{~K} / 33 / \mathrm{MEM} / 2007$. Secara geografis, WKP Ungaran terletak pada koordinat $110^{\circ} 18^{\prime} 42.36 "$ - $110^{\circ} 29^{\prime} 35.16^{\prime \prime}$ BT dan $7^{\circ} 07^{\prime} 42.69^{\prime \prime}-7^{\circ} 1544.96 "$ LS. Luas WKP adalah $29.800 \mathrm{Ha}$ dengan estimasi potensi sebesar $50 \mathrm{MWe}$.

Gunung Ungaran merupakan gunungapi Kuarter yang letaknya berada di utara Pegunungan Serayu Utara, dan merupakan hasil magmatisme belakang busur (back arc magmatism) dengan ketinggian sekitar $2.050 \mathrm{~m}$ dpl. Gunung Ungaran terletak di atas batuan dan tergabung dalam Formasi batuan tersier dan merupakan rangkaian paling utara dari jajaran gunungapi Ungaran - Telomoyo -
Merbabu - Merapi. Panas bumi Gunung Ungaran ditandai dengan mata air panas, fumarol, tanah panas, dan batuan ubahan.

Geologi komplek depresi Ungaran telah dibahas oleh beberapa peneliti, di antaranya van Bemmelen (1941, 1949), Von Padang (1951), Nikmatul Akbar (1983), Hadisantono dan Sumpena (1993), Thanden dkk. (1996). Pertamina (1983 - 1988) telah melakukan survei pendahuluan geosains dengan metode geologi, geokimia, geofisika dan pengeboran landaian suhu yang dilakukan pada tahun 1986 dan 1992, melalui sumur USL-1, UN-1, UN-2 dan melalui UN-3 untuk mengetahui keprospekan panas bumi di daerah ini. Selain itu beberapa tulisan ilmiah diantaranya Zarkasyi dkk (2011) telah membahas geosains dan zona prospek panas bumi daerah Ungaran.

Hasil riset dan tulisan-tulisan ilmiah tersebut belum menghasilkan suatu model 
konseptual panas bumi yang mengintegrasikan dan menginterpretasikan data geologi, geokimia, geofisika, dan sumur landaian suhu untuk mendeskripsikan sistem panas bumi yang terbentuk di daerah Gunung Ungaran. Tulisan ini mencoba membuat pemodelan sistem panas bumi berdasarkan data tersebut yang bertujuan untuk menggambarkan perkiraan geometri sistem panas bumi Gunung Ungaran.

\section{METODOLOGI}

Metode yang digunakan adalah kompilasi data geosains yang terdapat pada laporan riset dan tulisan ilmiah terdahulu. Hasil kompilasi diharapkan dapat merekontruksi gambaran bawah permukaan sistem panas bumi yang meliputi sumber panas, lapisan resevoir, lapisan penudung dan fluida panas.

Penafsiran kelurusan struktur geologi pada citra Landsat dan ASTER GDEM digunakan untuk memahami batasan sistem panas bumi dan vulkanisme. Korelasi data sumur landaian suhu USL-1, UN-1, UN-2 dan UN-3 dimaksudkan untuk menarik garis isotermal bawah permukaan.

Kerangka gambaran bawah permukaan diperoleh dari penampang tahanan jenis Magnetotelluric (MT) yang kemudian dikompilasikan dengan penampang geologi. Hasil akhir berupa model konseptual panas bumi Gunung Ungaran.

\section{HASIL DAN ANALISIS}

Daerah Ungaran memiliki beberapa manifestasi panas bumi yang tersebar di sekitar lereng timur hingga ke selatan dan di bagian barat laut sekitar Gonoharjo. Manifestasi terdiri atas mata air panas, fumarol, tanah panas, dan batuan ubahan. Mata air panas tersebar dalam enam kelompok yaitu di daerah Gedongsongo, Nglimut, Karangjoho, Diwak, Kali Ulo dan Jatikurung, sedangkan fumarol, tanah panas, dan batuan ubahan muncul hanya di sekitar Gedongsongo. Pada umumnya air panas bertemperatur $30-75^{\circ} \mathrm{C}$, dengan $\mathrm{pH}$ netral. Aktifitas fumarol yang berada di daerah Gedongsongo mempunyai temperatur antara $70-90{ }^{\circ} \mathrm{C}$ dan $\mathrm{pH} 3,5$ (asam). Mineral ubahan hidrotermal menunjukan mineral jenis kaolinit, penciri mineral asam yang terbentuk pada zona argilik. Munculnya fumarol dan belerang mengindikasikan daerah Gedongsongo merupakan daerah upflow dari sistem panas bumi Ungaran.

\section{Geologi Permukaan}

Morfologi Ungaran di bagian selatan memperlihatkan kenampakan morfologi yang tinggi dan terjal, tersusun oleh batupasir vulkanik dan breksi berumur Kuarter. Di bagian tengah hingga utara membentuk perbukitan bergelombang lemah, batuannya tersusun oleh breksi

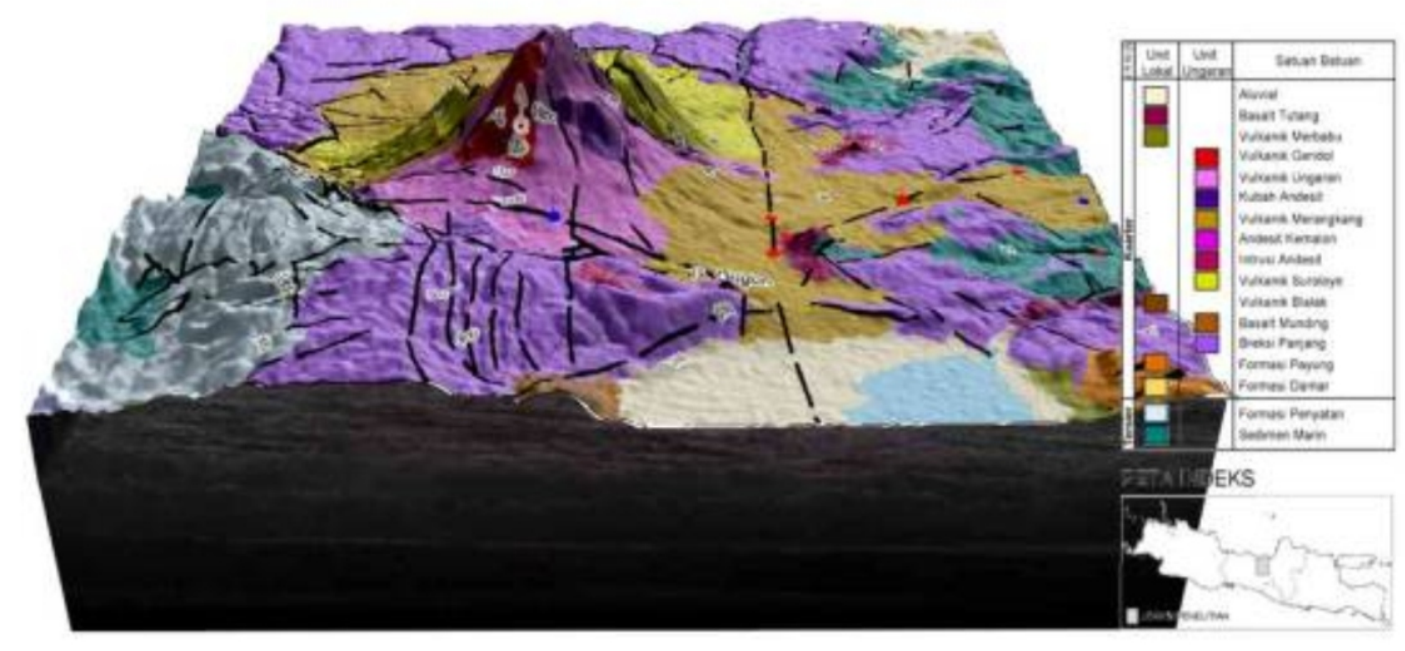

Gambar 1. Geologi daerah Ungaran (modifikasi dari Hadisantono dan Sumpena, 1993 dalam Thaden dkk., 1996) 
a)
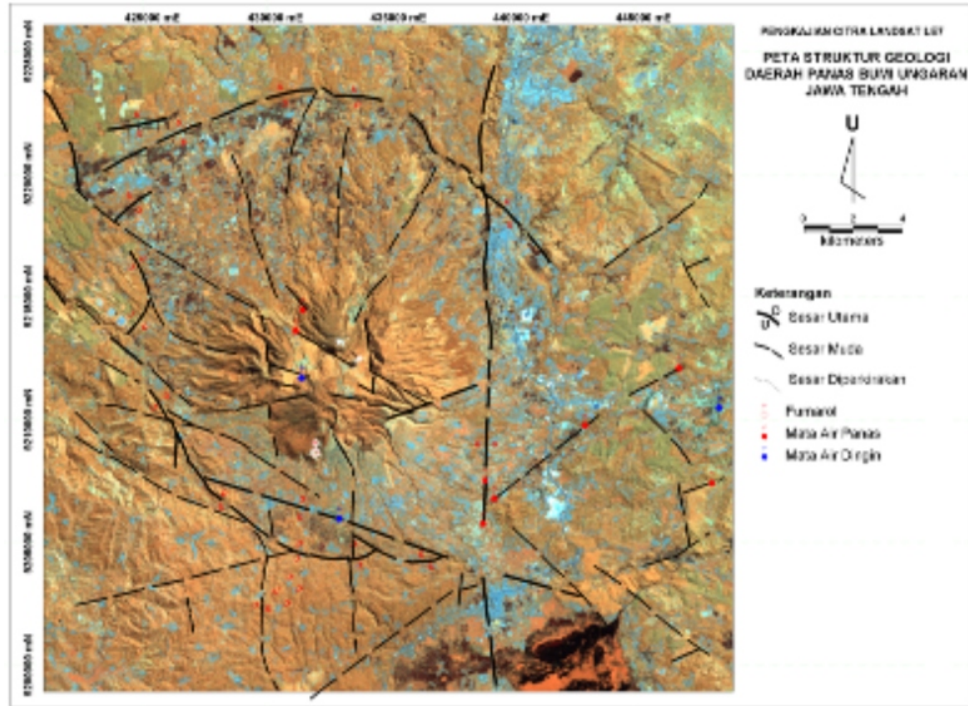

Neneraran

- 2essinuce

Eeser Desasdican

Funad

Mesiations

rargh

b)

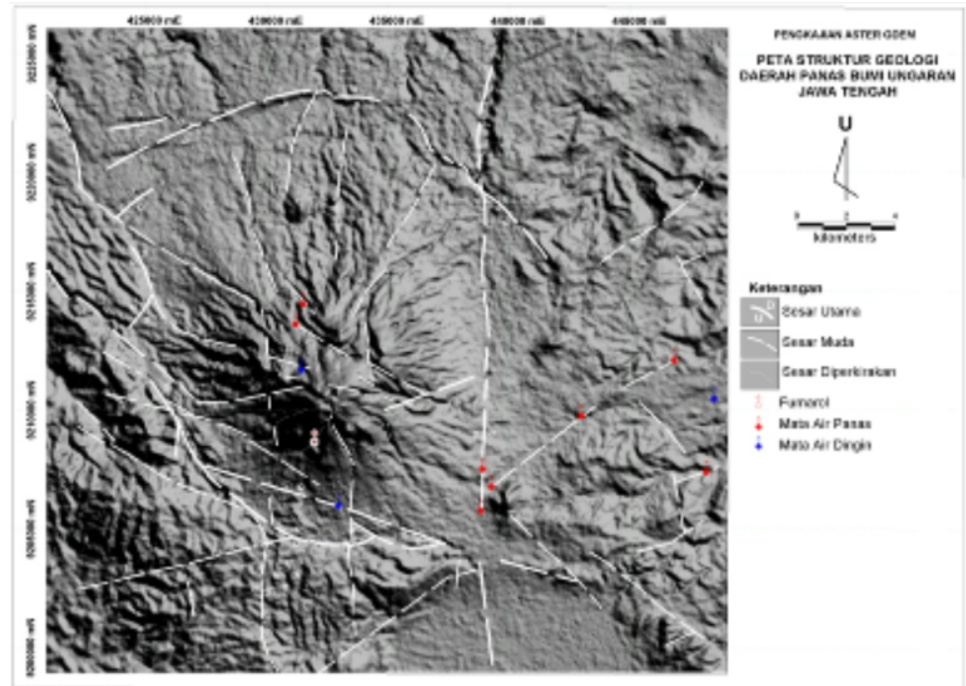

Gambar 2. a) Peta Struktur Geologi daerah Ungaran berdasarkan penafsiran Citra Landsat LE7

b) Peta Struktur Geologi daerah Ungaran berdasarkan penafsiran Citra ASTER GDEM setelah penafsiran dari Citra Landsat LE7

vulkanik Ungaran Tua dan Formasi Kalibiuk yang ditutupi endapan aluvial di bagian utara.

Komposisi batuan yang terdapat di Gunung Ungaran cukup bervariasi, terdiri dari basal olivin, andesit piroksen, andesit hornblende dan gabro. Batuan ubahan dijumpai di sekitar Gedongsongo yang ditunjukkan oleh munculnya mineral-mineral halosit, kaolinit, silika amorf, kristobalit, ilit, markasit, dan pirit. Batuan ubahan tersebut terdapat dekat fumarol dan mata air panas di sepanjang aliran Sungai Item. Asosiasi kelompok mineral ubahan yang terbentuk menunjukkan temperatur bawah permukaan lapangan panas bumi Gedongsongo berkisar antara $70^{\circ}-200^{\circ} \mathrm{C}$ dan bersifat asam (Indarto, 2006).

Sistem panas bumi yang berkembang di Gunung Ungaran secara geologi berada di zona depresi dengan litologi permukaan didominasi oleh batuan vulkanik berumur Kuarter berupa kerucut-kerucut muda. Struktur amblesan vulkanik (depresi) yang memanjang dari barat hingga tenggara mengontrol sistem panas bumi Ungaran. Batuan vulkanik penyusun pra-kaldera dikontrol oleh sistem sesar yang berarah barat laut-barat daya dan tenggara-barat daya. Pada Batuan vulkanik penyusun post- 
kaldera hanya terdapat sedikit struktur yang dikontrol oleh sistem sesar regional (Budiardjo et al. 1997).

Hasil analisis citra (Gambar 2.a dan b) menampilkan struktur sekunder yang berkaitan erat dengan sistem panas bumi Ungaran, dengan komplek vulkanik Ungaran dibatasi oleh struktur utama berarah baratlaut-tenggara hingga hampir barattimur pada batas bagian barat dan selatan. Kemudian struktur utama berarah utaraselatan yang memanjang hingga ke utara membatasi komplek vulkanik ini di bagian timur. Sedangkan di bagian utara komplek vulkanik Ungaran dibatasi oleh struktur utama berarah barat-timur hingga baratlauttenggara.

Pemunculan kelompok mata air panas Karangjoho dan Kaliulo dikontrol oleh struktur berarah timurlaut-baratdaya dan dibatasi oleh stuktur utama berarah utaraselatan yang membatasi komplek vulkanik Ungaran di bagian timur. Sementara pemunculan manifestasi Gedongsongo, Nglimut dan Baun dikontrol oleh zona struktur berarah utara-selatan sebagai pembatas pemunculannya dan struktur muda berarah baratlaut-tenggara sebagai media keluarnya manifestasi Nglimut dan struktur berarah timurlaut-baratdaya untuk manifestasi Gedongsongo.

\section{Geologi Bawah Permukaan}

Interpretasi dari data gaya berat (Anonim, 1986a) memperlihatkan tubuh dengan densitas $2,7-2,9 \mathrm{gr} / \mathrm{cm}^{3}$ terindikasi di bawah Gunung Ungaran berada pada kedalaman sekitar 250 - 400 m diduga merupakan magma yang yang menerobos sedimen Tersier. Anomali sisa (>10 mgal) membentuk kontur tertutup memperkuat dugaan adanya suatu tubuh batuan dengan densitas yang kontras dengan sekitarnya pada bagian utara Gunung Ungaran.

Nilai geolistrik (Anonim, 1985a) tahanan jenis semu tinggi menempati daerah elevasi tinggi sekitar Gunung Ungaran. Anomali tahanan jenis rendah yang terpetakan di area selatan diperkirakan sedimen Tersier, hingga kedalaman 500 meter.

Penurunan tahanan jenis seiring dengan bertambahnya kedalaman mempertegas keberadaan anomali rendah di bagian selatan dan timur. Lapisan batuan memiliki nilai tahanan jenis 5 - 20 ohmmeter hingga kedalaman 500 meter, dan diikuti anomali sangat rendah $<5$ ohmmeter yang menerus ke bawah.

Tahanan jenis semu MT dari data Pertamina (Anonim, 1984a) menunjukkan tahanan jenis rendah pada bagian selatan dan tenggara Gunung Ungaran. Anomali rendah di selatan dan tenggara ini diperkirakan sebagai sedimen Tersier. Lapisan konduktif di daerah Gedongsongo disisipi oleh lapisan batuan dengan tahanan jenis 11 ohmmeter hingga 15 ohmmeter, sedangkan di daerah Nglimut terindikasi lapisan batuan konduktif ( $<10$ ohmmeter) dan lapisan batuan bertahanan jenis intermedian $>20$ ohmmeter. Sisipan lapisan konduktif ini yang diperkirakan sebagai zona

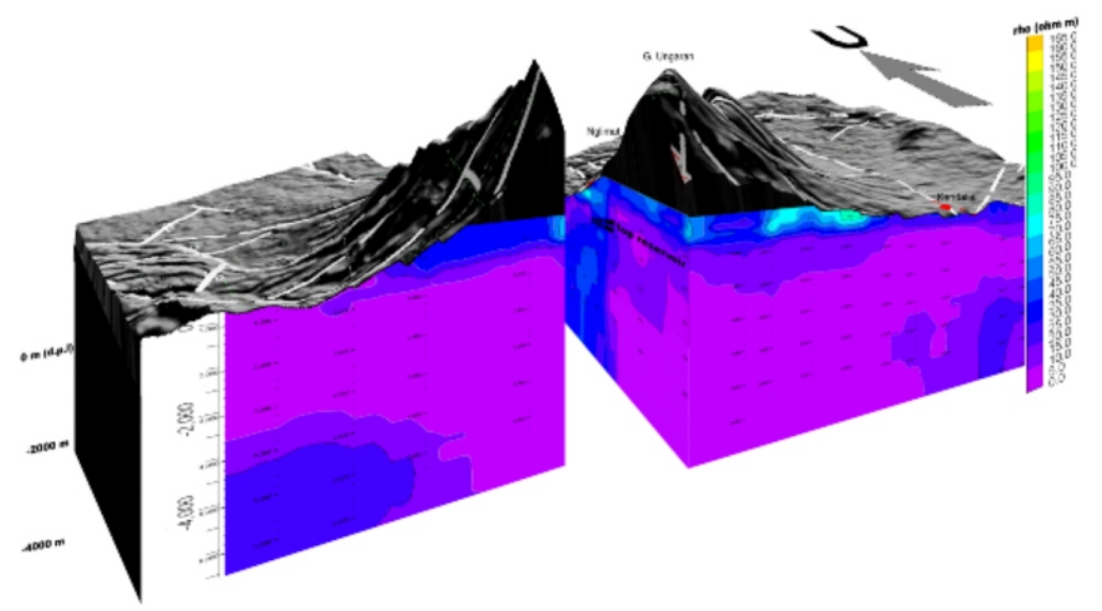

Gambar 3. Penampang tahanan jenis MT direkonstruksi dari data Pertamina (Anonim, 1984) 
penudung dari sistem panas bumi Ungaran sedangkan lapisan di bawahnya diduga merupakan resevoir.

Pengukuran MT juga dilakukan di sekitar lokasi manifestasi fumarol Gedongsongo (Widarto dkk., 2003). Hasil interpretasi MT menghasilkan model tahanan jenis yang mengindikasikan adanya kerucut intrusi yang diduga merupakan salah satu kerucut parasitik di Ungaran. Kerucut ini dicirikan oleh anomali tahanan jenis tinggi (>10.000 ohmmeter), diperkirakan merupakan intrusi andesit yang masih menyimpan panas dan dalam proses pendinginan. Lapisan permukaan, dengan tebal 400 m di bawah Kawah Item dengan nilai anomali lebih besar dari 1.000 ohmmeter, diinterpretasikan sebagai lapisan batuan yang disusun oleh lava dan breksi lahar andesitik yang terkompakkan. Di bawah lapisan ini diisi lapisan batuan bersifat konduktif ( $<10$ ohmmeter ) dengan tebal $200 \mathrm{~m}$ dan disusul lapisan tahanan jenis intermedian 30 hingga 300 ohmmeter mulai kedalaman 600 sampai 1.600 meter.

Dari data landaian suhu sumur USL-1, UN-1, UN-2, dan UN-3, secara umum menunjukkan bahwa stratigrafi batuan penyusun Gunung Ungaran terdiri dari perselingan lava andesit, endapan laharik dan piroklastik. Dari perselingan ini dapat ditarik kesimpulan bahwa Gunung Ungaran termasuk tipe stratovulkanik.

Landaian suhu di sumur USL-1 terhitung $10,4^{\circ} \mathrm{C} / 100 \mathrm{~m}$ atau sekitar 3 kali landaian suhu rata-rata bumi, dengan temperatur di dasar sumur pada kedalaman $500 \mathrm{~m}$ mencapai $52^{\circ} \mathrm{C}$. Sedangkan pengukuran tekanan menunjukkan tekanan di dasar sumur mencapai $38 \mathrm{~kg} / \mathrm{cm}^{2}$.

Tingkat ubahan batuan di sumur USL-1 lebih intensif dibandingkan dengan ketiga sumur lainnya, dengan tingkat ubahan dari menengah hingga kuat dan didominasi oleh mineral lempung dan klorit dari mulai kedalaman 0 - $500 \mathrm{~m}$. Terutama pada kedalaman 447 - $500 \mathrm{~m}$, didominasi oleh klorit dan kuarsa sekunder yang mencapai 12\% (Gambar 4).

Pada kedalaman $10-400,35 \mathrm{~m}$ di sumur USL-1 terdapat mineral apatit yang mengindikasikan alterasi yang berkaitan dengan intrusi, dan biasanya terdapat pada zona potasik. Kehadiran biotit sekunder juga mengindikasikan proses alterasi yang berkaitan dengan intrusi dan memperkuat dugaan bahwa di daerah ini pernah terjadi ubahan yang berkaitan dengan intrusi dengan kisaran temperatur antara 200 $400^{\circ} \mathrm{C}$.

Dari komposisi mineral sekunder maka tipe ubahan di sumur landaian suhu berjenis argillik hingga klorit, terbentuk pada kisaran temperatur $120-320^{\circ} \mathrm{C}$ dengan $\mathrm{pH}$ fluida bersifat asam-netral. Bila dikombinasikan antara rentang temperatur dari pembentukan mineral sekunder dengan data logging temperatur menunjukkan bahwa ubahan ini bersifat fosil.

Penampang korelasi temperatur bawah permukaan antar sumur menunjukkan bahwa garis isotermal di sumur UN-1 (berada di daerah manifestasi Karangjoho) menunjukkan kecenderungan naik dari sumur UN-3, dan kembali menurun di sumur UN-2 (Gambar 5). Hal ini memperkuat dugaan bahwa di daerah Kendalisodo terdapat suatu sistem geothermal tersendiri yang terpisah dengan sistem di Gedongsongo.

\section{PEMBAHASAN}

Daerah Panas Bumi Ungaran berada pada zona depresi vulkanik komplek Gunung Ungaran dengan banyak struktur geologi (kekar dan sesar) menjadikan daerah ini memiliki kemampuan untuk meloloskan air permukaan (meteoric water) ke bawah permukaan. Sebagian air meteorik tersebut kemudian berinteraksi dengan fluida magmatik dan gas-gas vulkanik yang berasal dari tubuh magma dan terjadi rambatan panas yang menghasilkan fluida panas.

Mata air panas yang muncul di Gedongsongo menunjukkan $\mathrm{pH}$ asam hingga netral, dengan tipe air sulfat. Kandungan gas $\mathrm{CO}_{2}$ dan $\mathrm{H}_{2} \mathrm{~S}$ tinggi disertai hembusan uap air dengan temperatur hembusan mencapai $90^{\circ} \mathrm{C}$. Kondisi ini menunjukkan bahwa daerah Gedongsongo berada di zone upflow pada suatu sistem reservoir dominasi air (water dominated), terutama ditunjang oleh keberadaan manifestasi fumarol. Sedangkan suplai fluida yang mengontrol mata air panas Nglimut berjenis bikarbonat yang mengindikasikan penciri zona outflow dari sistem panas bumi Ungaran. 


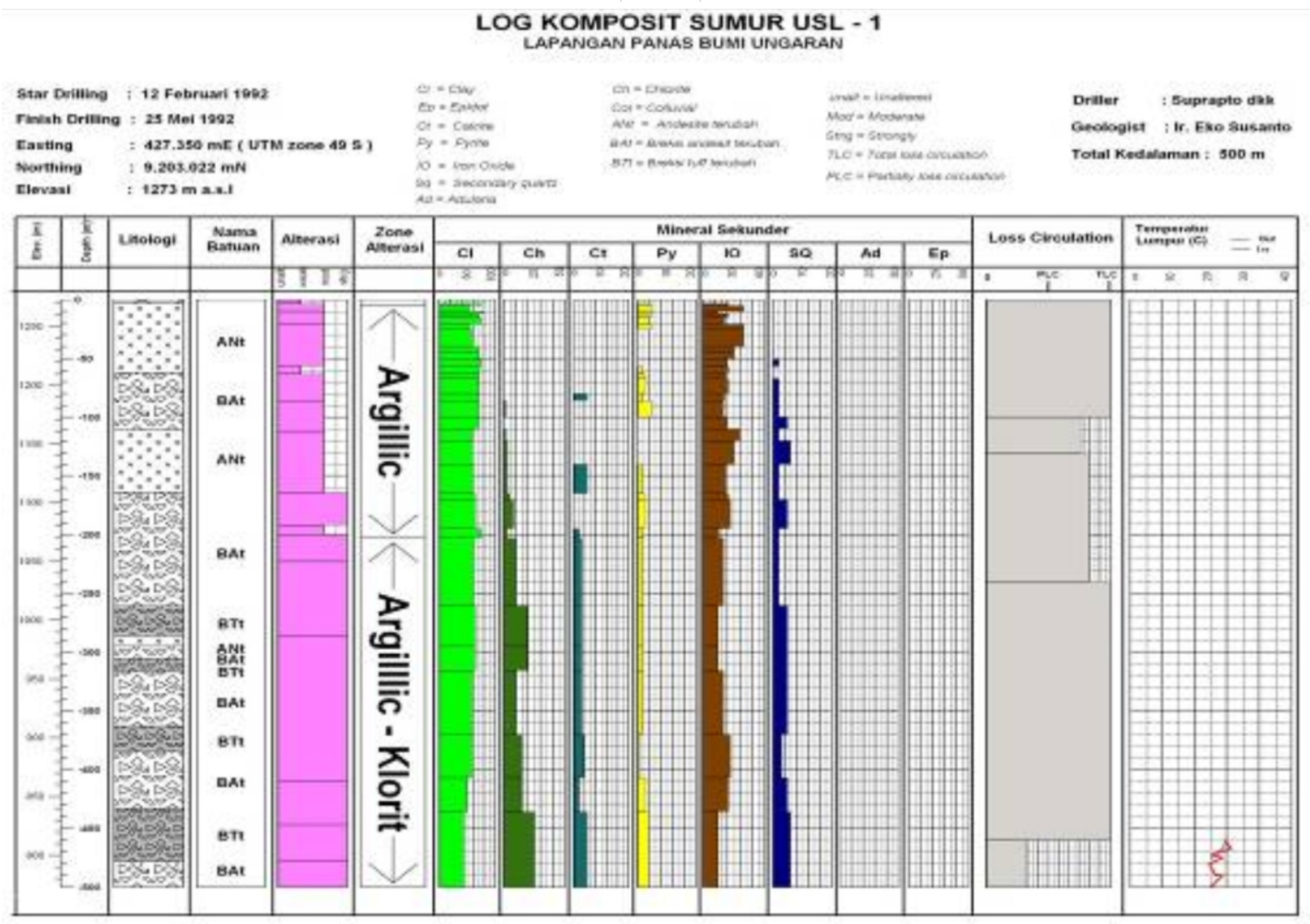

Gambar 4. Log komposit sumur USL-1 dimodifikasi dari data Pertamina (Anonim, 1986)

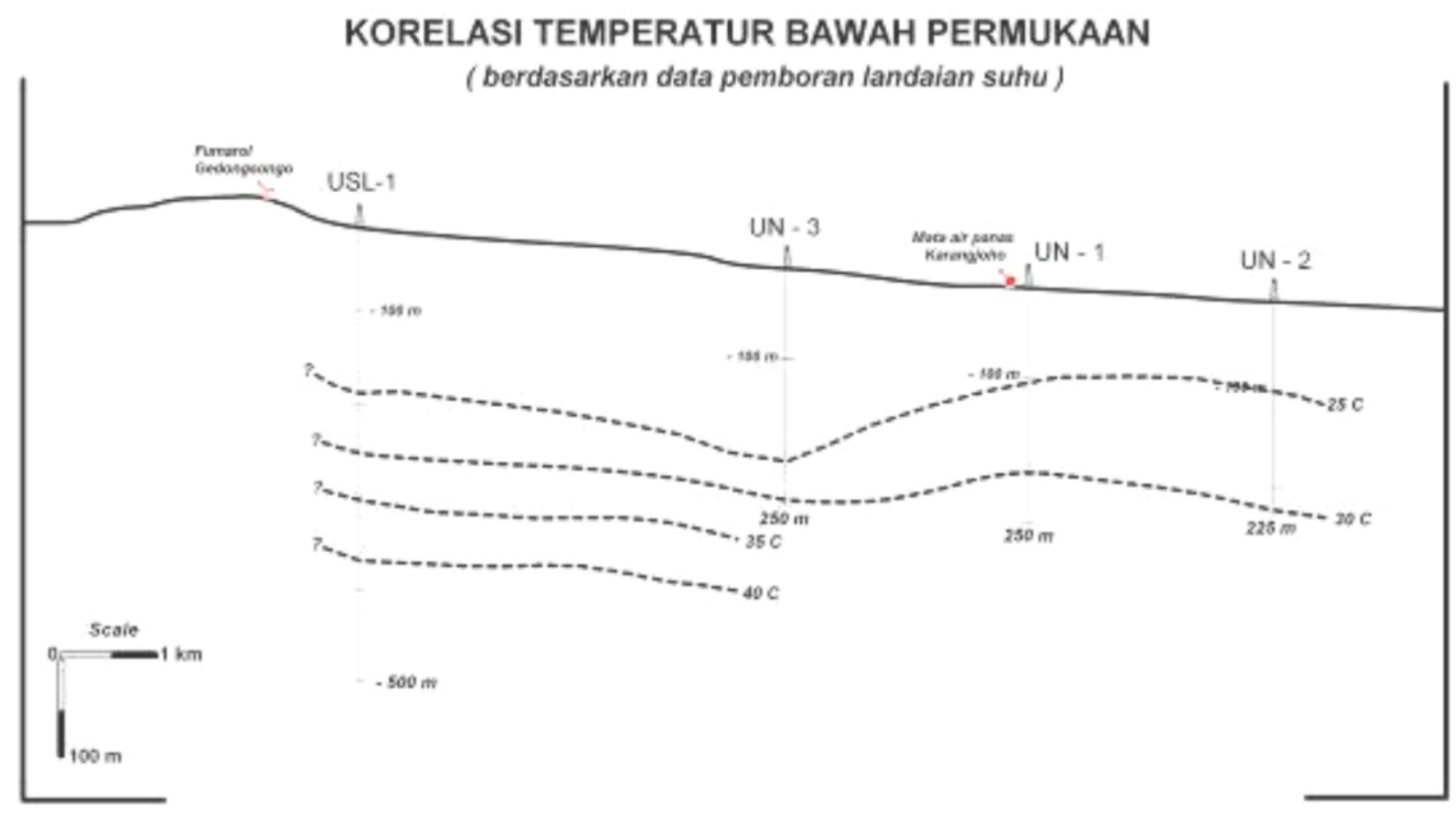

Gambar 5. Korelasi temperatur bawah permukaan berdasarkan hasil pengukuran survei landaian suhu oleh Pertamina (Anonim, 1986) 
Hasil estimasi temperatur reservoir dengan geotermometer gas dari fumarol Gedongsongo mencirikan adanya pengaruh unsur magmatis dengan temperatur lebih dari $300^{\circ} \mathrm{C}$ (Zarkasyi, dkk 2011).

Sistem panas bumi Ungaran terbentuk dengan batuan penudung berupa batuan ubahan bertipe argilik. Interpretasi MT, lapisan penudung ini memiliki ketebalan sekitar 300 - 500 m di daerah Nglimut dan sekitar $1400 \mathrm{~m}$ di daerah Gedongsongo (Zarkasyi, dkk 2011). Pendapat lain dari Widarto dkk., (2003) menyebutkan bahwa lapisan konduktif ( $<10$ ohmmeter) memiliki ketebalan $200 \mathrm{~m}$ dan disusul lapisan tahanan jenis intermedian $30-300$ ohmmeter mulai kedalaman 600 sampai $1.600 \mathrm{~m}$.

Puncak reservoir berada pada ketinggian sekitar $300 \mathrm{~m}$ di atas permukaan laut, dengan tahanan jenis diatas $30 \mathrm{ohm}-\mathrm{m}$. Reservoir diperkirakan terbentuk pada batuan vulkanik pra-Ungaran yang kaya dengan rekahan dan bersifat permeabel yang terbentuk akibat aktifitas struktur sesar yang ada atau akibat sifat fisik batuan itu sendiri yang berporositas baik, dan ini ada pada sedimen Tersier. Permeabilitas yang terdapat dalam batuan ini adalah permeabilitas primer berupa ruang antar butir yang saling berhubungan serta permeabilitas sekunder yang terbentuk akibat rekahan-rekahan. Dibawahnya ditempati batuan sedimen (meta-sedimen?) dianggap sebagai batuan dasar di daerah Ungaran.

Sumber panas sistem panas bumi Gedongsongo dan Nglimut diperkirakan dari sisa panas dapur magma Gunung Ungaran Muda berumur Kuarter. Sedangkan di daerah Kendalisodo sumber panas diperkirakan berasal dari tubuh intrusi yang berasosiasi dengan kubah lava andesitik Gunung Kendalis. Penampang landaian suhu yang menunjukkan garis isotermal cenderung naik pada sumur UN-1, memperkuat dugaan bahwa terdapat suatu sistem tersendiri di daerah Kendalisodo yang

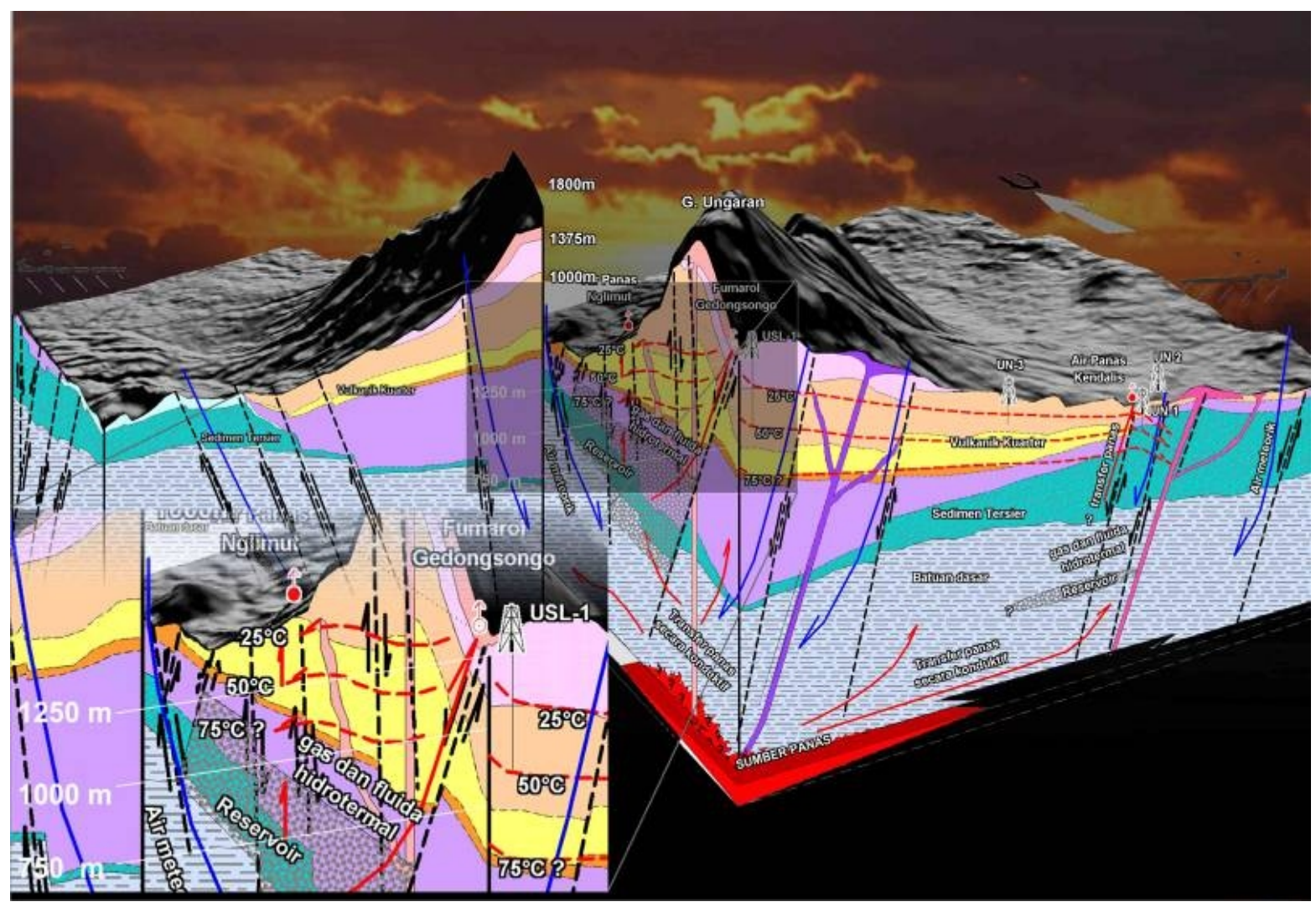

Gambar 6. Model konseptual daerah panas bumi Gunung Ungaran 
terpisah dengan sistem panas bumi di Gedongsongo. Dari hasil pembahasan, disajikan model konseptual daerah sistem panas bumi Ungaran (Gambar 6).

\section{KESIMPULAN}

Sistem panas bumi yang berkembang di Gunung Ungaran berada di zona depresi yang membatasi komplek vulkanik Gunung Ungaran dengan litologi permukaan didominasi oleh batuan vulkanik berumur Kuarter.

Adanya tubuh vulkanik dengan densitas 2,7 - 2,9 $\mathrm{gr} / \mathrm{cm}^{3}$ terindikasi di bawah Gunung Ungaran berada pada kedalaman sekitar $250-400 \mathrm{~m}$. Hal ini diperkuat oleh kehadiran mineral apatit dan biotit sekunder pada sumur USL-1 pada kedalaman 10 - 400,35 $\mathrm{m}$ yang mengindikasikan proses alterasi yang berkaitan dengan intrusi.

Lapisan konduktif di daerah Gedongsongo disisipi oleh lapisan batuan dengan tahanan jenis 11 - 15 ohmmeter, sedangkan di daerah Nglimut terindikasi lapisan batuan konduktif ( $<10$ ohmmeter), memiliki ketebalan sekitar $300-500 \mathrm{~m}$ di daerah Nglimut dan sekitar 1.400 m di daerah Gedongsongo.

Puncak reservoir berada pada ketinggian sekitar $300 \mathrm{~m}$ di atas permukaan laut, dengan tahanan jenis diatas $30 \mathrm{ohm}-\mathrm{m}$, terbentuk pada batuan vulkanik pra-Ungaran yang kaya akan rekahan dan bersifat permeabel dengan temperatur reservoir sebesar $300^{\circ} \mathrm{C}$.

Sumber panas sistem panas bumi Gedongsongo dan Nglimut diperkirakan dari sisa panas dapur magma Gunung Ungaran Muda. Sedangkan di daerah Kendalisodo sumber panas diperkirakan berasal dari tubuh intrusi yang berasosiasi dengan kubah lava.

\section{UCAPAN TERIMA KASIH}

Dalam proses penulisan paper ini, kami mengucapkan terima kasih kepada Bapak Sjafra Dwipa yang telah banyak memberikan masukan dalam penyelesaian paper serta seluruh staf Pusat Sumber Daya Geologi di Kelompok Penyelidikan Panas Bumi yang turut serta dalam berdiskusi tentang materi di tulisan.

\section{DAFTAR PUSTAKA}

Anonim, 1991. Survei $\mathrm{Hg}-\mathrm{CO} 2$ di daerah Ungaran, Jawa Tengah. Unpublish report Pertamina, Divisi Geotermal, Jakarta.

Anonim, 1987, Evaluasi akhir survey geokimia daerah Ungaran Jawa - Tengah. Unpublish report Pertamina, Divisi Geotermal, Jakarta.

Anonim, 1986a. Penyelidikan gayaberat Gunung Ungaran, Jawa Tengah. Unpubl. report Pertamina, Divisi Geotermal, Jakarta.

Anonim, 1986b, Laporan akhir pengeboran sumur dangkal daerah Ungaran Jawa - Tengah. Unpublish report Pertamina, Divisi Geotermal, Jakarta.

Anonim, 1985a. Ungaran resistivity survey, field and interpretation report. Unpublish report Pertamina, Divisi Geotermal, Jakarta.

Anonim, 1985b. Laporan Pengkajian Foto udara daerah Gunung Ungaran, Jawa Tengah. Unpublish report Pertamina, Divisi Geothermal, Jakarta.

Anonim, 1984a. Petrographic description of surface rock samples from Gunung Ungaran, Central Java. Unpublish report Pertamina, Divisi Geotermal, Jakarta.

Anonim, 1984b. Magnetotelluric survey for geo- thermal exploration in G. Ungaran Area. Central Java. Unpublish report Pertamina, Divisi Geotermal, Jakarta.

Anonim, 1983. Laporan Pendahuluan geologi daerah Gunung Ungaran, Jawa Tengah. Unpublish report Pertamina, Divisi Geotermal, Jakarta.

Indarto, S., 2006. Studi Batuan Vulkanik dan Batuan Ubahan Pada Lapangan Panas bumi Gedong-songo Komplek Gunung Ungaran, Geotek, LIPI.

Kenyon, C.S dan Beddoes, L. R. jr. 1977. Geothermal gradient map Southeast Asia. South East Asia Petroleum Explor. Soc. And Indonesia Petroleum Assoc., 50 p.

Muhardjo, Rab E S, Yusup R, Yuhan, Sundoro H., 1987. Penyelidikan geologi daerah panas bumi G.Ungaran Jawa Tengah. Unpublish report, Direktorat Vulkanologi, Bandung.

Nukman, M., 2009. Overview of Gedong-songo Manifestations, Ungaran Geothermal Prospect, Central Java, Indonesia: a preliminary account, Thirty-Fourth Workshop on Geo-thermal Reservoir Engineering Stanford University, Stanford, California. 


\section{MAKALAH ILMIAH}

Wahyudi, 2006., Kajian Potensi Panas Bumi Dan Rekomendasi Pemanfaatannya Pada Daerah Prospek

Gunungapi Ungaran Jawa Tengah. Berkala MIPA, 16(1)

Widarto, D. S, Gaffar E.Z., Yudistira T., Irianta B., Sunardi, 2003. Karakterisasi Sumberdaya Panasbumi Skala Kecil di Zona Depresi Volkanik Ungaran, Jawa Tengah, Geotek, LIPI.

Thaden, R.E., Sumadirja, H., Richards P.W., 1975, Peta Geologi lembar Magelang dan Semarang, Jawa Tengah, Direktorat Geologi.

Zarkasyi A., dkk., 2011, Review Geosain Untuk Menentukan Area Keprospekan Panasbumi Di Daerah Bandung.

Gunung Ungaran, Jawa Tengah. Buletin Sumber Daya Geologi, Pusat Sumber Daya Geologi, 